\title{
DEPENDENCE OF THE URBAN HEAT ISLAND ON THE ATMOSPHERIC CIRCULATION TYPES
}

Increased air temperature constitutes the basic feature of the urban climate. This phenomenon, referred to as the urban heat island, is characterized by a specific daily and annual rhythm.

The intensity of the urban heat island (as measured with the difference of air temperature between town and its peripheries $-\Delta T$ ) and the frequence of its occurrence depend upon the nature of the town (its magnitude, kinds of structures, number of inhabitants), local singularities (the influence of the bedding and the relief) and upon the weather conditions. The greatest influence on the formation of the heat island is exerted by the wind and cloudiness (the increase of these two factors decreases the intensity of the heat island), which are related to the synoptic situation. The anticyclonal situations are particularly conducive to the development of highly intensive heat islands $\left(\Delta T>3^{\circ} \mathrm{C}\right)$.

According to the data for the period of 1961-1965 the anticyclonal weather conditions in Warsaw accompanied the highly intensive heat islands in $58 \%$ of cases, the cyclonal ones in $28 \%$ of cases, and the separately treated weak gradient situations - in $14 \%$. The especially advantageous conditions for the development of the island are constituted by the high pressure situation over Poland (some $20 \%$ of cases), and the edge of the high pressure system from above the Western Europe or the Atlantic ocean (16\%). The frequencies quoted were established on the basis of the analysis of synoptic maps (Wawer, 1995, 1997).

The present report describes, on the other hand, the attempt at determination of dependence of the intensity of the urban heat island upon the atmospheric circulation types.

The empirical material used consisted of the everyday temperature differences $\Delta T$ measured at midnight ( 0 GMT) (the intensity of the heat island is as a rule the highest at that time) between downtown Warsaw (the weather station of the University of Warsaw) and the peripheries of town (Okęcie climatic station) over the period of 1976-1980, along with the types of atmospheric circulation defined according to classification of Osuchowska-Klein (1991), see Fig. 1. This period was not as typical as the 


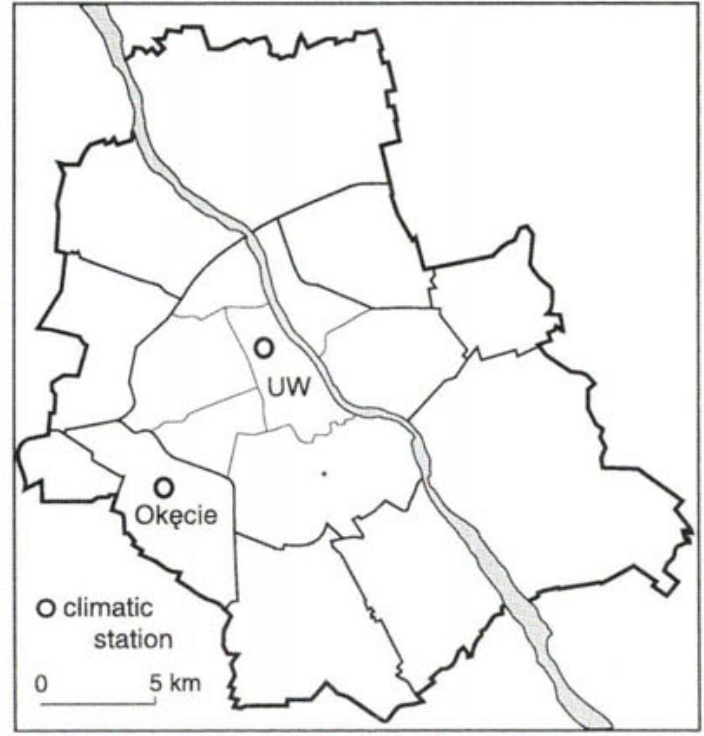

Fig. 1. Locations of climatic stations in Warsaw
1961-1965 five year period, due to the lesser share of circulation types with the western component.

During the five-year period considered the cyclonal settings constituted approximately $53 \%$ of situations, anticyclonal - approximately $44 \%$, while the remaining $3 \%$ were intermediate situations between the anticyclonal and cyclonal, as well as the undefined ones (Table 1). The most frequently appearing types were: $\mathrm{E}$ (anticyclonal - NE) - 19.3\%, CB (cyclonal - NW) - 17.5\%, and $\mathrm{E}_{0}$ (cyclonal - $\mathrm{NE}$ and $\mathrm{E}$ ) - $13.5 \%$, accounting altogether for more than $50 \%$.

The here considered fiveyear period 1976-1980 was generally characterized by a significant share of the types with eastern component $\left(\mathrm{E}_{0}, \mathrm{E}, \mathrm{E}_{1}, \mathrm{~F}\right)$, whose contribution amounted to $47 \%$. This had an important influence upon the analysed values of the air temperature differences $\Delta T$ in Warsaw (between the climatic stations of the University of Warsaw and Okęcie), since under such circumstances the peripheral station of Okęcie might get within the reach of the heat island, meaning that the temperature differences decrease.

Table 1

The frequency of the atmospheric circulation types during the five-year period 1976-1980

\begin{tabular}{|c|c|c|c|c|c|}
\hline \multicolumn{6}{|c|}{ Frequencies of circulation types in \% } \\
\hline \multicolumn{3}{|c|}{ cyclonal } & \multicolumn{3}{|c|}{ anticyclonal } \\
\hline $\mathrm{E}_{0}$ & $(\mathrm{NE}, \mathrm{E})$ & 13.5 & $\mathrm{E}$ & (NE) & 19.3 \\
\hline $\mathrm{F}$ & (SE) & 5.6 & $\mathrm{E}_{1}$ & $(\mathrm{E}, \mathrm{SE})$ & 8.7 \\
\hline B & $(\mathrm{S})$ & 5.7 & $\mathrm{D}_{2} \mathrm{C}$ & $(\mathrm{S}, \mathrm{SW})$ & 2.4 \\
\hline $\mathrm{D}$ & (SW) & 5.5 & $\mathrm{C}_{2} \mathrm{D}$ & (W) & 6.7 \\
\hline A & $(\mathrm{W})$ & 5.1 & $\mathrm{E}_{2} \mathrm{C}$ & $(\mathrm{NW})$ & 3.3 \\
\hline $\mathrm{CB}$ & (NW) & 17.5 & G & (central) & 3.9 \\
\hline \multicolumn{2}{|r|}{$\Sigma$} & 52.9 & & $\Sigma$ & 44.3 \\
\hline
\end{tabular}

According to the classification of Osuchowska-Klein.

The phenomenon of the urban heat island is so frequent that it can appear along with each of the circulation types. The positive air tempera- 
ture differences between downtown Warsaw and the peripheries occurred most frequently for the types which dominated in the period analysed: $\mathrm{E}$ (anticyclonal - NE), CB (cyclonal - NW) and $\mathrm{E}_{0}($ cyclonal - NE and E) see Table 2 .

Table 2

The frequency of atmospheric circulation types for various intensities of the urban heat island (in \%)

\begin{tabular}{|c|c|c|c|c|c|c|c|}
\hline $\begin{array}{c}\text { Cyclonal } \\
\text { types }\end{array}$ & $\begin{array}{l}\Delta T> \\
0.1^{\circ} \mathrm{C}\end{array}$ & $\begin{array}{l}\Delta T> \\
1^{\circ} \mathrm{C}\end{array}$ & $\begin{array}{l}\Delta T> \\
3^{\circ} \mathrm{C}\end{array}$ & $\begin{array}{c}\text { Anticyclonal } \\
\text { types }\end{array}$ & $\begin{array}{l}\Delta T> \\
0.1^{\circ} \mathrm{C}\end{array}$ & $\begin{array}{r}\Delta T> \\
1^{\circ} \mathrm{C} \\
\end{array}$ & $\begin{array}{l}\Delta T> \\
3^{\circ} \mathrm{C}\end{array}$ \\
\hline $\mathrm{E}_{0}(\mathrm{NE}, \mathrm{E})$ & 13.1 & 10.6 & 8.2 & $E(N E)$ & 18.7 & 21.7 & 21.6 \\
\hline$F(S E)$ & 4.9 & 3.3 & 3.0 & $E_{1}(E, S E)$ & 8.3 & 6.8 & 8.2 \\
\hline $\mathrm{B}(\mathrm{S})$ & 5.4 & 4.8 & 3.9 & $\mathrm{D}_{2} \mathrm{C}(\mathrm{S}, \mathrm{SW})$ & 2.6 & 3.6 & 4.6 \\
\hline $\mathrm{D}(\mathrm{SW})$ & 5.9 & 6.7 & 6.2 & $\mathrm{C}_{2} \mathrm{D}(\mathrm{W})$ & 7.5 & 8.3 & 10.5 \\
\hline$A(W)$ & 5.0 & 4.1 & 2.0 & $\mathrm{E}_{2} \mathrm{C}(\mathrm{NW})$ & 3.6 & 4.2 & 5.6 \\
\hline $\mathrm{CB}(\mathrm{NW})$ & 18.3 & 18.8 & 18.8 & G (central) & 4.2 & 5.0 & 7.5 \\
\hline$\Sigma$ & 52.6 & 48.3 & 41.3 & $\Sigma$ & 44.9 & 49.6 & 58.0 \\
\hline
\end{tabular}

The greater the share of the anitcyclonal circulations in comparison with the cyclonal ones, the bigger the difference of air temperatures between the downtown and the peripheries. High temperature differences $\left(\Delta T>3^{\circ} \mathrm{C}\right)$ are mainly linked with the following types: $\mathrm{E}, \mathrm{CB}, \mathrm{C}_{2} \mathrm{D}, \mathrm{E}_{1}$ and $\mathrm{G}$, and especially the anticyclonal ones, accounting for $58 \%$ of situations.

The average temperature differences between downtown and Okęcie in selected types of atmospheric circulation were calculated. In this analysis the set of 13 model circulation types was referred to, identified by the author of the classification of the circulation types as the optimal one for the description of atmospheric circulation over Poland. In the empirical classificatory assignment the similarity of a given atmospheric situation to the model pattern of circulation was assessed with the assumed distinction of three levels of similarity. These levels were denoted as follows (with TC being here the general symbol of circulation):

TC - circulation featuring a very high degree of similarity to the model type,

(TC) - circulation featuring high similarity to the model type (with a certain modification of the location or shape of the pressure setting),

$\left(\mathrm{X}_{\mathrm{TC}}\right)$ - circulation type displaying low similarity with respect to the model type (significantly differing from the model, but still considered similar).

It turned out that for the cyclonal types $\mathrm{E}_{0}$ (circulation - $\mathrm{NE}$ and $\mathrm{E}$ ) and $\mathrm{CB}$ (circulation - NW) the average differences of air temperature $\Delta T$ do not exceed $2^{\circ} \mathrm{C}$ (see Table 3 ).

Although both the average and the maximum values (up to $9-10^{\circ} \mathrm{C}$ ) are higher for the types with lower similarity than for the type with very high similarity to the model pattern, attention should be paid to the fact that the 
magnitude of the temperature difference $\Delta T$ between the station of the University of Warsaw and the one located in Okęcie is clearly influenced by the direction of circulation. Thus, in the anticyclonal types with the eastern component $\left(\mathrm{E}\right.$ and $\mathrm{E}_{1}$ ) the average values of $\Delta \mathrm{T}$ do not exceed, as well, $2^{\circ} \mathrm{C}$ and are similar or higher in the types with lower similarity to the model pattern: ( $\mathrm{X}_{\mathrm{E}}$ and $\mathrm{X}_{\mathrm{E}_{1}}$ ), while the extreme values $\Delta T_{\mathrm{MAX}}$ are higher in the types most akin to the model pattern $\left(\mathrm{E}, \mathrm{E}_{1}\right)$.

Table 3

The average and the extreme values of intensity of the heat island $(\Delta T)$ in selected types of circulation

\begin{tabular}{|l|c|c|c|}
\hline Circulation type & $\mathrm{E}_{0}(\mathrm{NE}, \mathrm{E})$ & $\left(\mathrm{E}_{0}\right)$ & $\left(\mathrm{X}_{\mathrm{E}_{0}}\right)$ \\
\hline$\Delta T\left({ }^{\circ} \mathrm{C}\right)$ & 0.9 & 1.2 & 1.5 \\
$\Delta T_{\mathrm{MAX}}\left({ }^{\circ} \mathrm{C}\right)$ & 3.5 & 9.0 & 5.8 \\
Type & $\mathrm{CB}(\mathrm{NW})$ & $(\mathrm{CB})$ & $\left(\mathrm{X}_{\mathrm{CB}}\right)$ \\
$\Delta T\left({ }^{\circ} \mathrm{C}\right)$ & 1.2 & 1.8 & 1.9 \\
$\Delta T_{\mathrm{MAX}}\left({ }^{\circ} \mathrm{C}\right)$ & 5.7 & 10.0 & 7.5 \\
Type & $\mathrm{E}(\mathrm{NE})$ & $(\mathrm{E})$ & $\left(\mathrm{X}_{\mathrm{E}}\right)$ \\
$\Delta T\left({ }^{\circ} \mathrm{C}\right)$ & 1.6 & 1.5 & 1.9 \\
$\Delta T_{\mathrm{MAX}}\left({ }^{\circ} \mathrm{C}\right)$ & 6.3 & 5.9 & 5.4 \\
Type & $\mathrm{E}_{1}(\mathrm{E}, \mathrm{SE})$ & $\left(\mathrm{E}_{1}\right)$ & $\left(\mathrm{X}_{\mathrm{E}_{1}}\right)$ \\
$\Delta T\left({ }^{\circ} \mathrm{C}\right)$ & 1.3 & 1.4 & 1.4 \\
$\Delta T_{\mathrm{MAX}}\left({ }^{\circ} \mathrm{C}\right)$ & 7.5 & 6.7 & 3.5 \\
Type & $\mathrm{D}_{2} \mathrm{C}(\mathrm{S}, \mathrm{SW})$ & $\left(\mathrm{D}_{2} \mathrm{C}\right)$ & $\left(\left(X_{D_{2} \mathrm{C}}\right)\right.$ \\
$\Delta T\left({ }^{\circ} \mathrm{C}\right)$ & 2.7 & 2.0 & 1.2 \\
$\Delta T_{\mathrm{MAX}}\left({ }^{\circ} \mathrm{C}\right)$ & 6.3 & 6.4 & 2.4 \\
Type & $\mathrm{C}_{2} \mathrm{D}(\mathrm{W})$ & $\left(\mathrm{C}_{2} \mathrm{D}\right)$ & $\left(\mathrm{X}_{\mathrm{C}_{2} \mathrm{D}}\right)$ \\
$\Delta T\left({ }^{\circ} \mathrm{C}\right)$ & 2.1 & 1.7 & 2.1 \\
$\Delta T_{\mathrm{MAXX}}\left({ }^{\circ} \mathrm{C}\right)$ & 6.3 & 6.0 & 3.7 \\
Type & $\mathrm{E}_{2} \mathrm{C}(\mathrm{NW})$ & $\left(\mathrm{E}_{2} \mathrm{C}\right)$ & $\left(\mathrm{X}_{\mathrm{E}_{2} \mathrm{C}}\right)$ \\
$\Delta T\left({ }^{\circ} \mathrm{C}\right)$ & 2.2 & 2.4 & 1.6 \\
$\Delta T_{\mathrm{MAX}}\left({ }^{\circ} \mathrm{C}\right)$ & 6.6 & 3.3 & 5.9 \\
$\mathrm{Type}$ & $\mathrm{G}(\mathrm{central})$ & $(\mathrm{G})$ & $\left(\mathrm{X}_{\mathrm{G}}\right)$ \\
$\Delta T\left({ }^{\circ} \mathrm{C}\right)$ & 2.3 & 2.2 & 2.9 \\
$\Delta T_{\mathrm{MAX}}\left({ }^{\circ} \mathrm{C}\right)$ & 5.9 & 6.7 & 5.0 \\
\hline
\end{tabular}

In the remaining anticyclonal types featuring the components $\mathrm{S}, \mathrm{SW}, \mathrm{W}$ and NW and in the central type the average values of $\Delta T$ are higher than in the types with the eastern component (e.g. $2.9^{\circ} \mathrm{C}$ in the $\mathrm{X}_{\mathrm{G}}$ type), but the extreme values are the highest in the "pure" types, most similar to the model pattern (Table 3).

Hence, it is beyond doubt that the magnitude of thermal differentiation between the downtown and the peripheries depends upon the type of atmo- 
spheric circulation, with the particularly large impact of the anticyclonal situations. Given the here considered choice of weather stations in Warsaw the value of $\Delta T$ is also influenced by the direction of circulation, especially from the eastern sector, since under such circumstances the peripheral station (Okęcie) may come under the influence of the heat island and the temperature differences will significantly decrease.

\section{REFERENCES}

Os u ch ow sk a-Kle in B., 1991, Katalog typów cyrkulacji atmosferycznej (The catalogue of atmospheric circulation types; in Polish), Wyd. IMGW, Warszawa.

W a w e r J., 1995, Wplyw warunków pogodowych na intensywność miejskiej wyspy ciepła $w$ Warszawie (The impact of weather conditions on the intensity of the urban heat island in Warsaw; in Polish), in: Klimat i bioklimat miast, Wyd. Uniwersytetu Łódzkiego, Łódż.

W a w e r J., 1997, Miejska wyspa ciepła w Warszawie (Urban heat island in Warsaw; in Polish), Prace $i$ Studia Geograficzne, vol. 20. Wyd. UW, Warszawa. 
